\title{
PRODUCTION OF A PRODUCT SIMILAR TO GELATIN FROM CHICKEN FEET COLLAGEN
}

\section{POLIANA F. DE ALMEIDA ${ }^{1}$, FELIPE A. CALARGE ${ }^{2}$, JOSÉ CARLOS C. SANTANA ${ }^{3}$}

\begin{abstract}
Chicken feet can be used as an alternative source of collagen for the development of new products. In this sense, the aim of this study was the production of a product similar to gelatin from collagen extracted from chicken feet and the evaluation of sensory quality. The products were produced in two distinct flavors, with grape flavor called GU and pineapple flavor called GA. Subsequently, we compared these formulations with gelatin of a trademark established in the market. We used in the verification of sensory acceptability of products a hedonic scale of 9 points and the availability of consuming the product by 30 untrained tasters. According to the results, all formulations showed good levels of acceptability, indicating the collagen from chicken feet as an alternative source of high quality in the production of gelatin.
\end{abstract}

KEYWORDS: chicken feet; quality; sensory analysis, utilization of byproduct; new product development.

\section{PRODUÇÃO DE UM PRODUTO SIMILAR A GELATINA A PARTIR DE COLÁGENO DE FRANGO}

RESUMO: Os pés de frango podem ser aproveitados como fonte alternativa de colágeno no desenvolvimento de novos produtos. Neste sentido, objetivou-se com o presente estudo a produção de um produto similar a gelatina a partir de colágeno extraído de pés de frango e a avaliação da qualidade sensorial. Os produtos foram elaborados com dois sabores distintos, sendo uva denominada GU e sabor abacaxi denominada GA. Posteriormente, compararam-se as formulações com uma gelatina de marca comercial consolidada no mercado. Utilizou-se, na verificação da aceitação sensorial, dos produtos escala hedônica de 9 pontos e a disponibilidade em se consumir o produto mediante 30 provadores não treinados. De acordo com os resultados, todas as formulações obtiveram bons níveis de aceitabilidade, indicando o colágeno dos pés de frango como fonte alternativa de elevada qualidade na produção de gelatinas.

PALAVRAS-CHAVE: pés de frango; qualidade; análises sensoriais; aproveitamento de subproduto; desenvolvimento de novo produto.

\section{INTRODUCTION}

According to FIORELLI et al. (2010) the broiler industry in Brazil has shown strong growth regarding to productive and commercial factors, standing out in the international market since 1995 with higher rates of growth in production and worldwide export. This led Brazil in 2004to hold the position of world's largest exporter in that year. This position is maintained until the present time, with an annual production of 3.8 million tons in 2010, and the forecast for 2011 is to surpass 4 million tons (AVISITE, 2011; NASCIMENTO et al., 2011; SALGADO \& NAAS, 2010).

The southeast region of Brazil is the second major producer region in the country, with $28 \%$ of housed birds, especially in the state of São Paulo, with 18\% (NASCIMENTO et al., 2011;

\footnotetext{
${ }^{1} \mathrm{~B}^{\mathrm{el}}$ Tecnologia de Alimentos, Mestre em Engenharia de Produção pela UNINOVE, Prof ${ }^{\mathrm{a}}$. Titular do Instituto Federal de Educação, Ciência e Tecnologia de Mato Grosso - Campus São Vicente-MT, Fone: (65) 33412106, e-mail: poliana.fernandes@ hotmail.com, Bolsista PROSUP/CAPES.

${ }^{2}$ Engenheiro Mecânico, Doutor em Engenharia Mecânica e em Economia pela UNICAMP, Prof. Titular do Programa de PósGraduação em Engenharia de Produção, UNINOVE, fcalarge@uninove.br.

${ }^{3} \mathrm{~B}^{\text {el }}$ Química Industrial, Doutor em Engenharia Química pela UNICAMP, Bolsista do CNPq em Produtividade em Pesquisa, Prof.

Titular do Programa de Pós-Graduação em Engenharia de Produção, UNINOVE, jccurvelo@uninove.br.

Recebido pelo Conselho Editorial em: 2-6-2011
}

Aprovado pelo Conselho Editorial em: 28-5-2013 
SALGADO \& NAAS, 2010). Great part of the destination of export of chicken meat is countries with specific requirements of housing, related to the welfare of the birds (FURTADO et al., 2010; OWADA et al., 2007).

The per capita consumption of chicken meat has increased significantly in recent years, from $29.9 \mathrm{~kg}$ in 2000 to $38.1 \mathrm{~kg}$ in 2009. This increase in consumption due to lower product price and technological gains (UBA, 2009), generates a large amount of underutilized housing components. The waste and effluents from the production chain of meat and products of poultry, cattle and swine production have high polluting power and if arranged in inadequate methods, generate serious environmental problems that lead to degradation of soil, surface and ground water environments, and health problems and death of living beings, by the presence of pathogenic microorganisms and animals and poisonous insects (ABREU NETO \& OLIVEIRA, 2009; SILVA \& ROSTON, 2010; DUDA \& OLIVEIRA 2009a and 2009b; MATOS et al., 2010; ORRICO JUNIOR et al., 2010a).

An alternative to reduce the environmental impacts caused by incorrect disposal is the treatment and/or reuse of these wastes (PADILHA et al., 2006). Recent researches mention the reuse of poultry litter and carcass composting for obtaining humus (ORRICO JUNIOR et al., 2010b). In general, biodigesters are used to degrade wastewater from swine (ORRICO JUNIOR et al., 2010a) or cattle raising (XAVIER \&LUCAS JUNIOR, 2010), which can be used to generate methane gas to be used as fuel and mud that can be used as organic fertilizer (humus).

Similar to other agricultural activities, the poultry production generates a large amount of waste that, if well managed, could become not only an important source of income and add value to the activity, but also a sustainable production model that is increasingly becoming a requirement of the market. Therefore, the adoption of a system of waste treatment is necessary in order to avoid possible contamination of the environment (ORRICO JUNIOR et al., 2010a and 2010c).

The waste may contain many substances of high value. If appropriate technology is employed, this material can be converted into commercial products or raw materials for secondary processes (GIRAÇOL et al., 2011). In this sense, many food residue before disposed of as useless substances currently are transformed into products of wide commercial acceptance. According to ROQUE \& SELL (2009) an alternative to reuse waste is to develop new products that use or give them a nobler destiny, with more commercial value. Alternative ways of recycling or reuse of solid waste should be searched. For this purpose, new technologies are been developed, such as the use of different materials to cover the installations (FIORELLI et al., 2010), improvement of animal's food quality (EYNG et al., 2011; MINAFRA et al., 2010; NASCIMENTO et al., 2009) and the use of biogas for heating of poultry houses (SANTOS et al., 2007). ORRICO JUNIOR et al. (2010c) investigated the technical feasibility of using anaerobic digestion to treat waste from poultry litter and carcasses of pre-composted poultry.

Thus, the raw material that is considered a waste in some areas, in other areas is the base of traditional byproducts with added value potential. We mention some Asian countries, where chicken feet are considered a delicacy, but in Brazil, it is one of the poultry cuts that consumers are less interested (PADILHA et al., 2006). Thus, the selling of a ton of chicken feet is below $1.00 \mathrm{R} \$ / \mathrm{t}$. These characteristics of the domestic market are crucial to set your low sale value (MFRURAL, 2010). With the increasing world population, it is necessary to search for alternative food as a way to meet the demand. However, to achieve their goals, these alternative sources should not only contain nutritious food produced in large scale and low cost but also provide good sensory characteristics (COSTA et al., 2008).

The development of new food products is been investigated through the discovery of new food sources or reuse of byproducts or waste. To this end, in addition to the sensory aspects, nutritional aspects should be taken into account, so that they can meet any vitamin or minerals need without a rejection of the product by the consumer. In this context there are the so-called functional foods (BARIMALAA \& OKOROJI, 2009; LENTZ, 2008). 
Regular consumption of gelatin is good for the human tissue, because collagen is responsible for cicatrization and tissue regeneration. In the case of hair and nails, collagen forms a matrix where the minerals are attached to keep them strong, durable and bright. For the skin, the nutrient offers more elasticity, besides being an excellent ally for people with low calorie diets due to high contents of protein containing no fat and carbohydrates. Collagen has lots of water, which helps give sense of satiety after eating. For these reasons gelatin is always present in hospital diets (ALMEIDA et al., 2012; ROMAN et al., 2009; SCHUMANN et al., 2008).

The gelatin can be extracted from skin or bones of animals after acidic or basic pretreatment (KASANKALA et al., 2007). The use of unconventional hides of animals slaughtered for commercial purposes has been disseminated in the country. Among the types of hides used, stands out the fish skin and hides of ostrich paws. Thus, SILVA et al. (2009) developed a model that calculates the surface area of chickens to enable scaling of the hide and hence its commercial viability.

ALVES \& PRUDÊNCIO-FERREIRA (2002) extracted collagen from chicken skins and feet. The yield of dehydrated collagen material was about $16 \%$ relative to the weight of skins and tendons "in natura", and can be used in the production of edible gelatin. In Brazil, gelatin is produced in abundance and at low cost (OSAWA et al., 2009), based on 2004 data, it is estimated that the worldwide market for gelatin moves more than U\$ 2 billion per year (LIMA et al., 2008). Gelatin is widely used in food, cosmetics and pharmaceuticals industry, being produced in large scale and relatively low prices, thereby justifying the great interest in their use due to their multifunctional properties: ability to form stable and reversible gels (SEGTNAN \& ISAKSSON, 2004).

Most commercial gelatins are derived from mammalian sources, mainly pigs and cattle, but due to sociocultural restrictions (Islam and Judaism) and the frequent occurrence of diseases such as bovine spongiform encephalopathy, which cause problems for human health, end up limiting the use of products derived from mammals for processing of functional foods, cosmetics and pharmaceuticals (ALMEIDA et al., 2012; CHO et al., 2005). Thus, we can affirm that there is a growing interest in developing alternative sources of raw materials as the use of chicken feet and fish byproducts.

The search for alternative sources to obtain gelatin is also an environmental issue, as one of the most important problems of leather industry is the generation of waste. In the treatment of bovine hide for the production of gelatin, a solution of caustic soda is used to dissolve undesirable organic substances such as fats and proteins, and there is a concern to prevent its disposal as effluent (LIMA et al., 2008).

This search for new agents of gelification to replace gelatin of mammals guided various researches on different raw materials, such as gelatin of marine origin (fish skin, bones and fins) (HAUG et al., 2004), and other studies that focus on the extraction and classification of gelatin from fish (ANERSEN \& GILBERG, 2007; GOMEZ- ESTACA et al., 2009), but it is a little used source since according to ARNESEN \& GILDBERG (2007) nowadays, the production of fish gelatin is only $1 \%$ of the entire annual production of gelatin in the world.

However, alternative sources should not only contain nutritious food produced in large scale and low cost but also provide good sensory characteristics (COSTA et al., 2008). In this sense, it appears that two factors prevail in the purchase decision of the consumer: price and quality. Knowing that one of the parameters of food quality is sensory, the importance of the methods of sensory analysis is reinforced, and this tool is increasingly used in the food industry (ROMAN et al., 2009).

In this context, the aim of this study was to obtain a product similar to gelatin using collagen extracted from chicken feet and evaluate their sensory qualities comparing them with a trademark. 


\section{MATERIAL AND METHODS \\ Development of gelatins}

The raw materials used in processing of the product similar to gelatin were freshly slaughtered chicken feet from the IFMT - Campus of São Vicente. The production of gelatin using chicken feet is a relatively quick and easy process, but it needs a lot of care during handling, considering that is a product from raw material that is an optimal culture medium for the development of microorganisms. Therefore, the adoption of Good Manufacturing Practice is essential for the safety of the final product.

First, the chicken feet were washed, the nails removed and washed again with cold water to remove any residues of dirt. After, they were submitted to the cooking in heating mantle (model 102 , Fisatom, Brazil) at a temperature of $120^{\circ} \mathrm{C}$ for 20 minutes, then following the sequence in Figure 1.

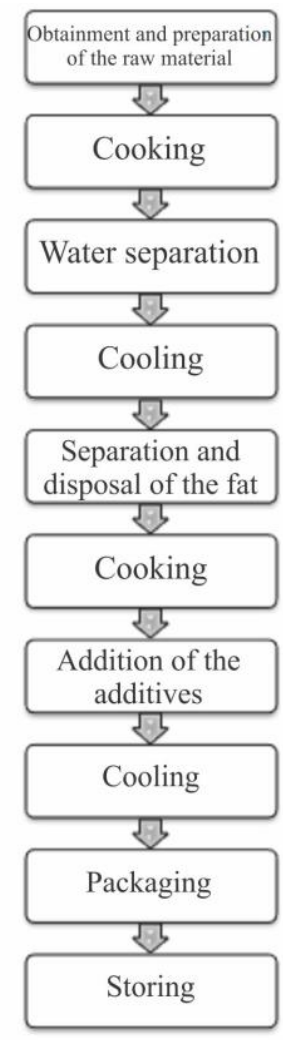

FIGURE 1. Flow chart of production of gelatin from chicken feet.

The gelatins were prepared according to the method found in ANERSEN \& GILDBERG (2007), CHO et al. (2005), HAUG et al. (2004), IRWANDI et al. (2009), KASANKALA et al. (2007) and ROMAN et al. (2009) and described as follows:

After cooking, the resulting liquid portion, composed of collagen, fat and water, was separated, filtered in cotton and the sample was placed in a glass recipient being subjected to cooling at room temperature. After cooling, the fat accumulated on the surface due to the lower density, facilitating its separation with the aid of a spoon and later disposal. The mixture of $500 \mathrm{ml}$ of collagen and water was placed in a stainless steel recipient and heated together with $200 \mathrm{~g}$ of sugar and additives. Two samples of product similar to gelatin were prepared from the collagen of chicken feet named GA and GU. The GA sample was made with pineapple flavor and the sample called GU with grape flavor.

In the GA sample we added yellow pigment and pineapple essence, as well as ascorbic acid, citric acid and potassium sorbate preservative. In the GU sample we added $0.5 \mathrm{~g}$ of potassium sorbate preservative and 10g of SIBER ${ }^{\circledR}$ (grape flavor), the composition included pigments, starch, acidifiers, acidity regulator and antiwetting agent. The commercial gelatins used for the comparison were of the trademark Dr. Oetker® grape flavor (GUC) and pineapple flavor (GAC). 


\section{Sensory Evaluation}

The sensory evaluation was performed by 30 untrained tasters of both sexes, aged between 15 and 25 years. The analyses were conducted in individual booths in the Sensory Evaluation Laboratory (LASA) of the IFMT - Campus of São Vincente. The samples, cooled at a temperature of about $15^{\circ} \mathrm{C}$, were served in disposable plastic cups in amounts of about $5 \mathrm{~mL}$, coded, and the order was of random presentation (ALMEIDA et al., 2008 and 2010, ALMEIDA et al., 2012).

The tasters had at their disposal a glass of water that was used to rinse the mouth between the analyses of the samples. The answers were recorded on standardized forms describing the intensities of the sensations that the food caused on the evaluators, both in standard hedonic scales. They evaluated the attributes color, flavor, aroma, texture and the availability in consuming the product, using the affective test with structured hedonic scale of 9 points, ranging from 1- I dislike extremely to 9- I like extremely to the questions color, aroma, flavor and texture and the test of predisposition to consumption with scale of 1- not to consume to 6- consume everyday (ALMEIDA et al., 2008 and 2010; ANDRAE-NIGHTINGALE et al., 2009; MADRONA et al., 2009; SANTANA et al., 2010; STERN JR et al., 2007; SILVA et al., 2010).

From the relative values of acceptability, we could infer the preference, i.e., the most accepted samples are the most preferred and vice versa. The results obtained from the questionnaires were tabulated, in view of the frequency of responses using tool as the statistical analysis of variance and the t-Student test, as ALMEIDA et al. (2010), FREIRE et al. (2009) and SANTANA et al. (2010).

\section{RESULTS AND DISCUSSION}

Table 1 shows the yield of extracted material from chicken feet. As seen, the material that can be used in the production of gelatin is about $36 \%$ of the total weight of chicken feet used. Thus, $1.0 \mathrm{t}$ of chicken feet acquired can get up to $355.4 \mathrm{~kg}$ of collagen, which is a pretty significant income, especially considering that 1.0t of raw material is purchased for only R $\$ 1.00$ (MFRURAL, 2010).

TABLE 1. Chemical composition of "in natura" chicken feet.

\begin{tabular}{lc}
\hline Components & Mean value (g/100g) \\
Humidity (\%) & 64.46 \\
Collagen (\%) & 35.54 \\
\hline
\end{tabular}

Source: ALVES \& PRUDÊNCIO-FERREIRA (2002).

Table 2 shows the mean values of the sensory analysis of the product similar to gelatin of collagen from chicken feet and the commercial sample. Analyzing the averages, it appears that the commercial gelatin showed values close to or above 8 , for all sensory qualities, indicating that most of the tasters said they "loved" this gelatin. As for the gelatin of collagen from chicken feet the values varied close to 7 , indicating that most of the tasters said they "liked" this product.

The statistical analysis by t-Student showed no significant differences between the samples for flavor and texture qualities. However, significant differences between the color and the flavors of the samples were observed, and the commercial gelatin stood on the gelatin obtained from collagen of chicken feet; although it did not disqualify the gelatin, as its value exceeds the scale of "like moderately".

TABLE 2. Evaluation of the sensory qualities of the gelatins from chicken feet, grape flavor.

\begin{tabular}{c|c|c|c|c}
\hline \multicolumn{5}{c}{ Mean Sensory Values } \\
\hline Samples & Aroma & Color & Flavor & Texture \\
\hline Commercial Grape Gelatin (GUC) & $8.1^{\mathrm{a}}$ & $8.3^{\mathrm{a}}$ & $8.4^{\mathrm{a}}$ & $7.9^{\mathrm{a}}$ \\
\hline Experimental Grape Gelatin (GU) & $7.7^{\mathrm{a}}$ & $7.5^{\mathrm{b}}$ & $7.0^{\mathrm{b}}$ & $6.4^{\mathrm{a}}$ \\
\hline
\end{tabular}

${ }^{1}$ Means followed by different letters on the same column indicate significant differences between the samples. 
Although not significant, we assumed that this small difference in attribute "texture" means is due to the fact that the experimental grape gelatin presented a more consistent texture than the products available in the market, causing some weirdness to the consumers accustomed with the products of lower consistence. Which can be seen by the amount of water present in the samples, since a larger amount of water in the composition makes the product less consistent than others. Figure 2 shows the sensory values of the samples in GU and GUC in hedonic graphic scale to a better understanding of the results, showing that the averages distance themselves only for values of taste, agreeing with the statistical analysis.

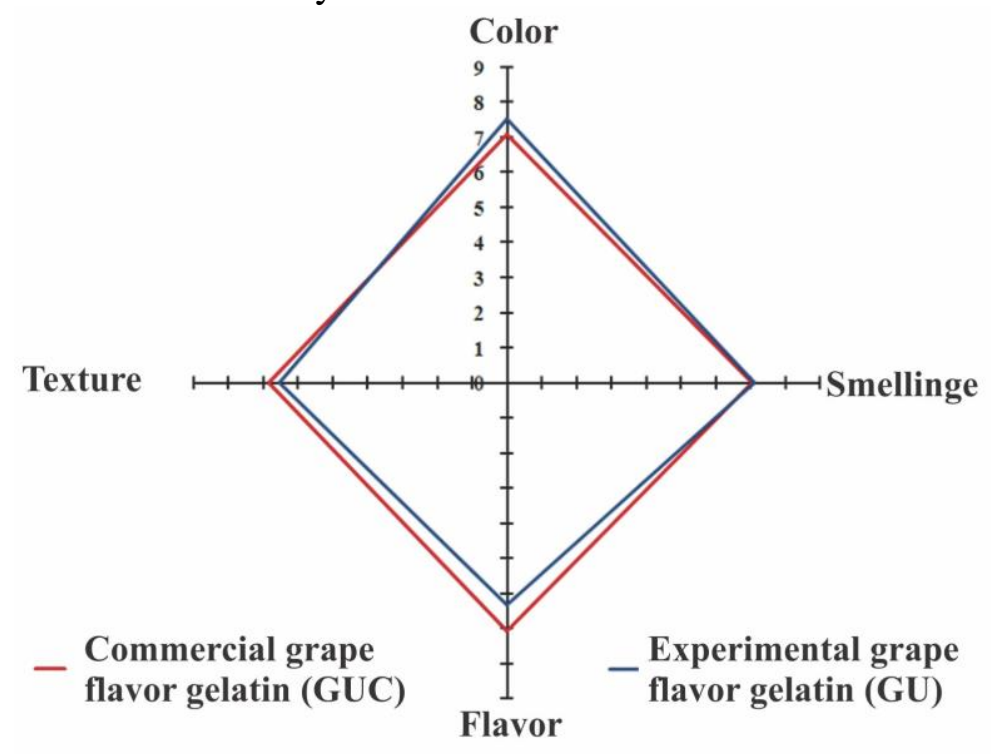

FIGURE 2. Distribution, in hedonic scale, of the values obtained for the sensory qualities of the gelatins.

Figure 3 presents the responses to the availability to consume the gelatin samples obtained from the sensory test responses. We can notice that the values assigned by the tasters for consume intentions of formulation GUC were slightly higher and showed a lower rejection of their consumption relative to the values obtained for the $\mathrm{GU}$ formulation. To the intention "consume occasionally" the experimental gelatin formulation (GU) stood out with $26.6 \%$ while the commercial gelatin (GUC) showed $16.6 \%$ of the frequency of the assigned values. However, over $83 \%$ of the evaluators said they had intention to consume the product similar to gelatin obtained from collagen of chicken feet (GU), indicating that this can also be commercialized, as its acceptance was high.

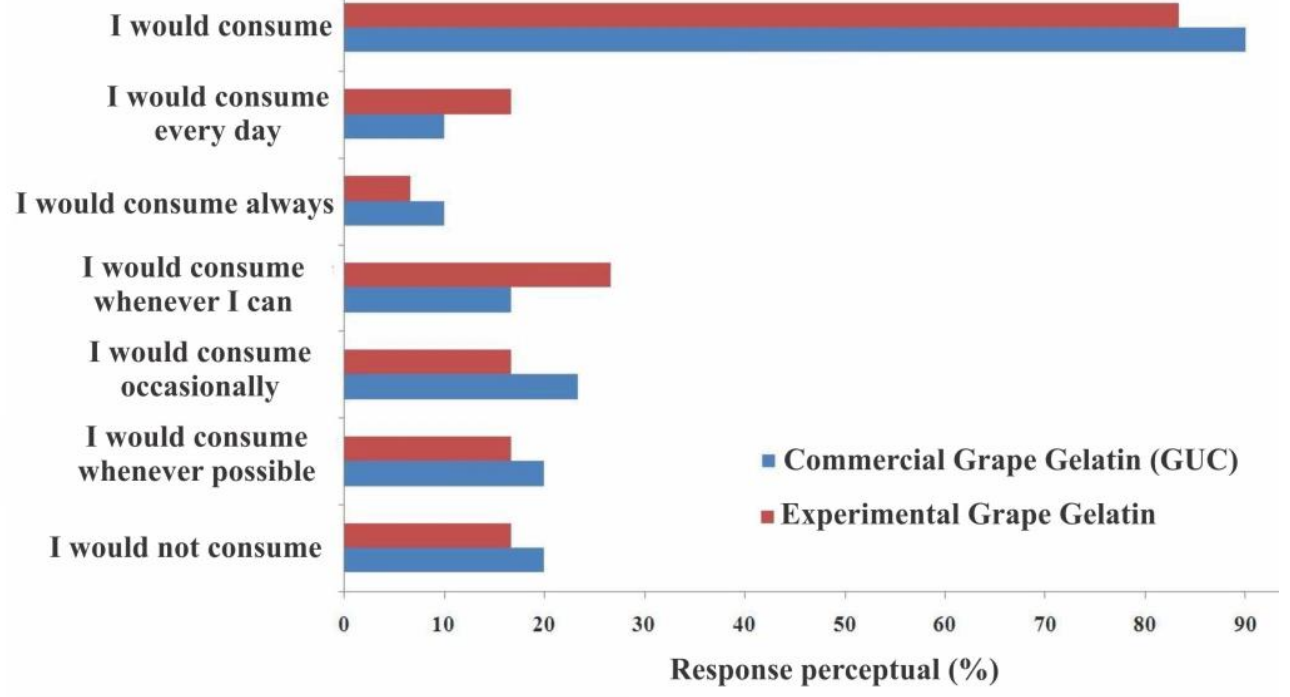

FIGURE 3. Frequence of the attributed values in availablity to consume the product. 
Table 3 shows the mean values obtained in the sensory analysis of collagen chicken feet gelatin (GA) and commercial sample (GAC), flavored with pineapple. According to the results obtained in the hedonic scale test of the gelatin samples, we did not observed difference at $5 \%$ of significance between samples for aroma, taste, color and texture. However, analyzing the obtained averages, it appears that for flavor and color the experimental pineapple gelatin presented slightly higher averages indicating classification between "like moderately" and "like extremely", while for flavor and texture the commercial gelatin showed slightly higher averages with classification obtained between "like slightly" and "like moderately".

TABLE 3. Evaluation of sensory qualities of gelatins from chicken feet, pineapple flavor.

\begin{tabular}{c|c|c|c|c}
\hline \multicolumn{5}{c}{ Mean Sensory Values } \\
\hline Samples & Aroma & Color & Flavor & Texture \\
\hline $\begin{array}{c}\text { Commercial Pineapple } \\
\text { Gelatin }\end{array}$ & $7.0^{\mathrm{a}}$ & $7.1^{\mathrm{a}}$ & $7.1^{\mathrm{a}}$ & $6.8^{\mathrm{a}}$ \\
\hline $\begin{array}{c}\text { Experimental Pineapple } \\
\text { Gelatin }\end{array}$ & $7.1^{\mathrm{a}}$ & $7.5^{\mathrm{a}}$ & $6.3^{\mathrm{a}}$ & $6.5^{\mathrm{a}}$ \\
\hline
\end{tabular}

${ }^{\mathrm{I}}$ Means with same letters indicate that there are no differences between samples.

The same consideration made above for the GU sample in the small difference found in the attribute "texture", can be considered for the GA sample, which also presented less consistence than the commercial sample GAC. Figure 4 shows the sensory values in hedonic graphical scale to the better understanding of the results.

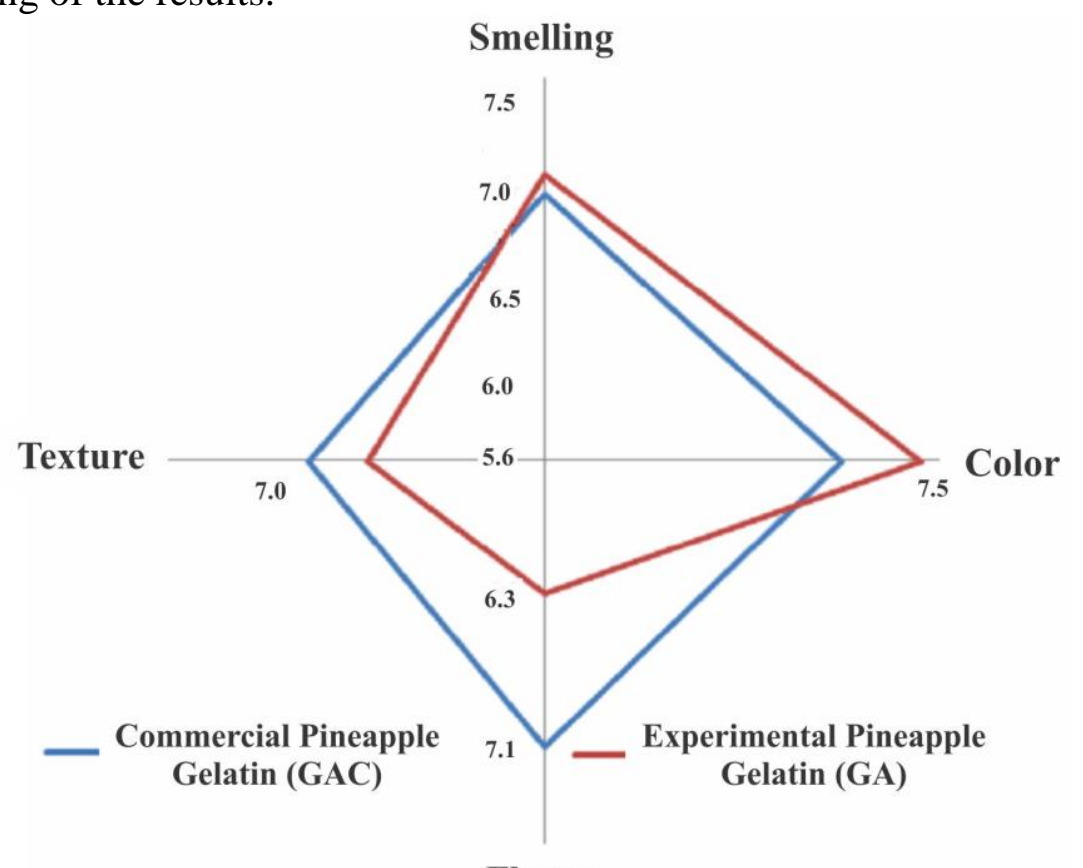

Flavor

FIGURE 4. Distribution in hedonic scale of the values obtained for the sensory qualities of the gelatins.

Figure 5 demonstrates the availability to consume the samples of pineapple gelatins available. We found that the frequency of the values assigned by the tasters for experimental gelatin was slightly higher in the classifications of "consume occasionally" and "consume whenever possible" where the formulation of experimental pineapple gelatin (GA) stood out with $16.6 \%$ and $26.6 \%$ respectively, while the commercial gelatin (GAC) showed $6.6 \%$ and $23.3 \%$ of the frequency of the values assigned respectively. 


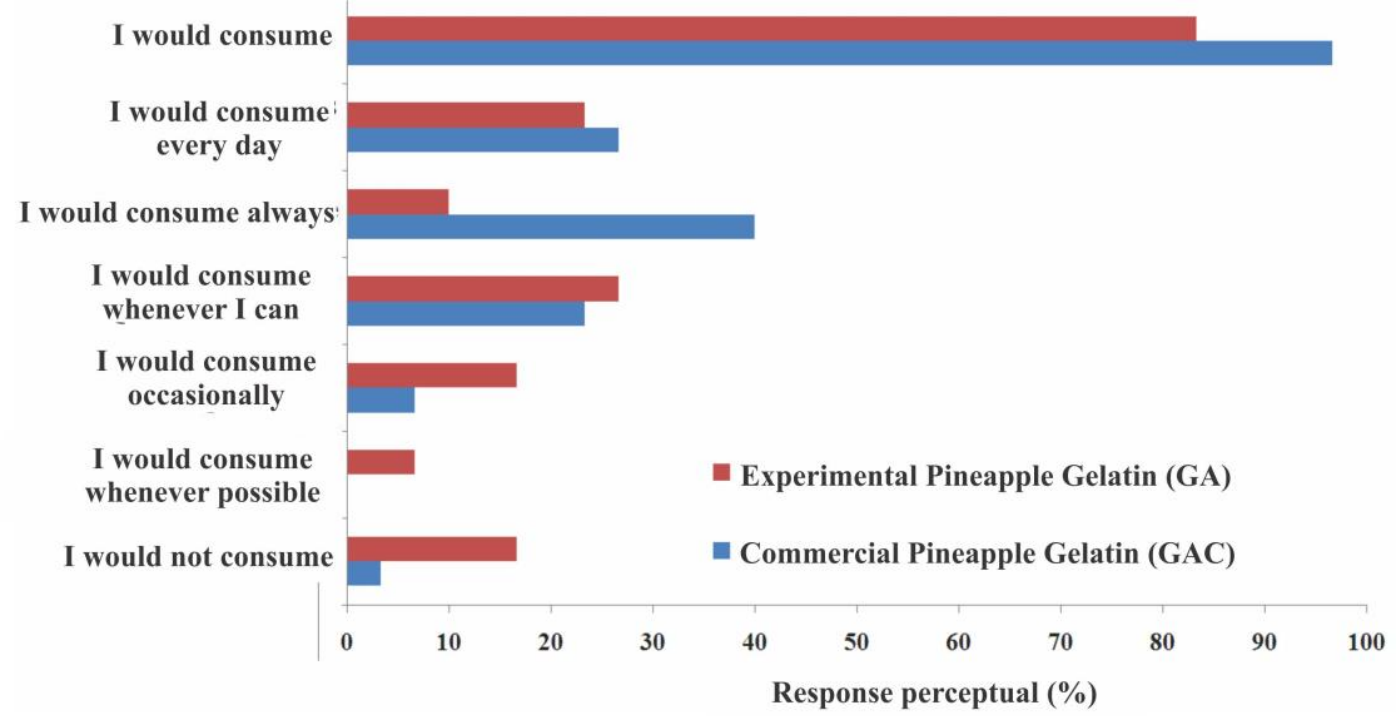

FIGURE 5. Frequence of the attributed values in availablity to consume the product.

In general, as the results obtained in the formulation of grape gelatin, about $83 \%$ of the tasters assumed the intention to consume the product similar to gelatin with pineapple flavor (GA), demonstrating good product acceptability.

According to ALVES \& PRUDÊNCIO-FERREIRA (2002), the raw material used to obtain the gelatin is rich in protein and minerals, which makes it a very nutritious food. Table 4 gives a comparison between the experimental and commercial samples of gelatins, with respect to its chemical composition. The comparison of the values for the constituents of chicken feet collagen gelatin (GU and GA) with the commercial gelatin (GUC and GAC) shows that the quantities of proteins of the first are 4 times greater than of the second, which demonstrates an extremely higher quality of the gelatin obtained in this study, compared to the commercial one. Thus, the daily consume of a gelatin obtained from chicken feet would be equivalent to the consumption of four commercial gelatins, maintaining the same nutritional properties of protein.

TABLE 4. Chemical composition of the chicken feet and commercial gelatins.

\section{Components}

Humidity

Proteins (g)

Sodium (g)
Mean values $(\mathrm{g} / \mathbf{1 0 0 g})$

\section{Chicken feet collagen gelatin}

6.4

Commercial gelatin

8.5

Dry basis
$1.6^{* *}$

$247 \mathrm{mg}$

*ALVES \& PRUDÊNCIO-FERREIRA (2002) and **DR. OETKER BRASIL (2010)

Final considerations:

- the cost to obtain the raw material is irrelevant, since $1.0 t$ cost only $\mathrm{R} \$ 1.00$;

- the raw material receives a nobler destiny;

- increase the profits of industries that produce chicken meat and thus improve the quality of life of surrounding communities;

- as $1.0 \mathrm{t}$ of chicken feet generates $355.4 \mathrm{~kg}$ of gelatin (dry) and the current gelatin packages are commercialized with 45g (DR OETKER BRAZIL, 2010), we can say that 1.0t of raw material produce 7,898 packages of gelatin, with the same $\mathrm{R} \$ 1.00$ spent on their acquisition; 
- the methods and equipment used to obtain the current gelatins would not be modified;

- avoid additional costs for implementation of new techniques and equipment and the training of personnel (GELITA, 2010);

- the obtainment of gelatin from chicken feet is more hygienic than obtaining gelatin from animal hides such as pigs and cattle;

- this product has no rejection like those derived from cattle or pigs regarding the Islamic and Jewish communities (ALMEIDA et al., 2012; CHO et al., 2005);

- from the marketing point of view, mention that the product is obtained from chicken feet is much better than mention that the gelatin is obtained from bovine or pig hides, because it would have a better acceptance of audience.

\section{CONCLUSIONS}

The products similar to gelatin obtained from chicken collagen have no significant differences regarding the commercial gelatins for the flavor and texture attributes.

The majority of the tasters approved the gelatins obtained from collagen of chicken feet, rating them between "like" and "like moderately", while over $80 \%$ said they would consume this product. The levels of protein and sodium of the gelatin from chicken feet collagen outcome in four times the levels of the commercial gelatin levels, indicating superiority in its chemical quality comparing to the commercial one.

The obtained product has a good quality, with low cost enabling the replacement of the raw material currently used for the presented in this study.

\section{ACKNOWLEDGEMENTS}

To the PROSUP/CAPES program and the CNPQ by the scholarships granted and to the UNINOVE to the financial support during the development of this research.

\section{REFERENCES}

ABREU NETO, M. S. e OLIVEIRA, R. A. Remoção de matéria orgânica, de nutrientes e de coliformes no processo anaeróbio em dois estágios (reator compartimentado seguido de reator UASB) para o tratamento de águas residuárias de suinocultura. Engenharia Agrícola, Jaboticabal, v. 29, n. 1, 148-161, 2009.

ALMEIDA, S. S.; SOUZA, R.R.; SANTANA, J.C.C.; TAMBOURGI, E.B. Sensorial analysis of wines from Malpigia glaba L. pulp. Brazilian Journal of Operation and Production Management, v. 5, n.1, 1-12, 2008.

ALMEIDA, S. S.; NARAI, N.; SOUZA, R. R.; SANTANA, J. C. C. Optimization of processing conditions for wine production from acerola (Malpighia glaba L.). Acta Horticulturae ISHS, The Hague, v. 864, p.471 - 478, 2010.

ALMEIDA, P. F.; ARAÚJO, M. G. O.; SANTANA, J. C. C. Collagen extraction from chicken feet for jelly production. Acta Scientiarum. Technology, Maringá, v. 34, n. 3, 345-351, 2012.

ALVES, S. G. T.; PRUDÊNCIO-FERREIRA, S. H. Propriedades funcionais de material colagenoso de pés de frango. Archivos Latinos Americanos de Nutricion, v. 52, n.3, p., 289-293, 2002.

ANDRAE-NIGHTINGALE, L. M.; LEE, S. - Y.; ENGESETH, N. J. Textural changes in chocolate characterized by instrumental and sensory techniques. Journal of Texture Studies, v. 40, p. 427 444, 2009.

ANERSEN, J. A.; GILDBERG, A. Extraction and characterisation of gelatin from Atlantic salmon (Salmo salar) skin. Bioresource Technology, Essex, v. 98, p. 53 - 57, 2007. 
AVISITE. Estatística e preço: Receita cambial do frango cresce quase $50 \%$ em relação a janeiro de 2010. Disponível em: 〈http://www.avisite.com.br/economia/estatistica.asp?acao=exportacao〉. Acesso em: abr. 2011.

BARIMALAA, I. S.; OKOROJI, C. O. Particle Size Distribution of Commercial Cowpea (Vigna unguiculata (L) Walp.) Flour and Sensory Properties of Akara. International Journal of Food Engineering, v. 5, n. 4, p.1-5, 2009.

COSTA, D. P. S.; ROMANELLI, P. F.; TRABUCO, E. Aproveitamento de vísceras não comestíveis de aves para elaboração de farinha de carne. Ciência e Tecnologia de Alimentos, Campinas, v. 28, n. 3, p. 746-752, 2008

CHO, S.M.; GU, Y.S.; KIM, S.B.; Extracting optimization and physical properties of yellowfin tuna (Thunnus albacares) skin gelatin compared to mammalian gelatins. Food Hydrocolloids, Oxford, v. 19, p. 221-229, 2005.

DR OETKER BRASIL. Produtos: gelatinas. Disponível em: http://www.oetker.com.br . Acesso em: 20 abr. 2010.

DUDA, R. M.; OLIVEIRA, R. A. Reatores anaeróbios operados em batelada sequencial, seguidos de lagoas de polimento, para o tratamento de águas residuárias de suinocultura. Parte I: produção de metano e remoção de DQO e de sólidos suspensos. Engenharia Agrícola, Jaboticabal, v. 29, n. 1, p. 122-134, 2009a.

DUDA, R. M.; OLIVEIRA, R. A. Reatores anaeróbios operados em batelada sequencial seguidos de lagoas de polimento para o tratamento de águas residuárias de suinocultura. Parte II: remoção de nutrientes e coliformes. Engenharia Agrícola, Jaboticabal, v. 29, n. 1, p. 135-147, 2009b.

EYNG, C.; NUNES, C. G. V.; NUNES, R. V.; ROSTAGNO, H. S.; ALBINO, L. F. T.; VIEITES, F. M.; POZZA, P. C. Composição química, valores energéticos e digestibilidade verdadeira dos aminoácidos de farinhas de carne e ossos e de peixe para aves. Revista Brasileira de Zootecnia, Viçosa-MG, v. 40, n. 3, p. 575-580, 2011.

FIORELLI, J.; FONSECA, R.; MORCELI, J. A. B.; DIAS, A. A. Influência de diferentes materiais de cobertura no conforto térmico de instalações para frangos de corte no oeste paulista. Engenharia Agrícola, Jaboticabal, v. 30, n. 5, p. 986-992, 2010.

FREIRE, M. T. A.; PETRUS, R. R.; HASHIDA, J. C.; FAVAROTRINDADE, C. S. Avaliação física, química e sensorial de doce cremoso de goiaba acondicionado em bisnaga plástica. Brazilian Journal of Food Technology, Oxford, v. 12, n. 3, p. 172-180, 2009.

FURTADO, D. A.; ROCHA, H. P.; NASCIMENTO, J. W. B.; SILVA, J. H. V. Índices de conforto térmico e concentração de gases em galpões avícolas no semiárido Paraibano. Engenharia Agrícola, Jaboticabal, v. 30, n. 6, p. 993-1002, 2010.

GELITA. A produção de gelatina. Manual. Disponível em: 〈http://www.gelita.com〉. Acesso em: 18 abr. 2010.

GIRAÇOL, J.; PASSARINI, K. C.; SILVA FILHO, S. C.; CALARGE, F. A.; TAMBOURGI, E. B.; SANTANA, J. C. C. Reduction in ecological cost through biofuel production from cooking oils: An ecological solution for the city of Campinas, Brazil. Journal of Cleaner Production, Amsterdam, v. 19, n. 12, p. 1324-1329, 2011.

GÓMEZ-ESTACA, J.; MONTERO, P.; FERNÁNDEZ-MANTÍN, F.; GÓMEZ-GUILLÉN, M.C. Physico-chemical and film-forming properties of bovine-hide and tuna-skin gelatin: A comparative study. Journal of Food Engineering, Essex, v. 90, p. 480-486, 2009.

HAUG, I.J.; DRAGET, K. I.; SMIDSROD, O. Physical and rheological properties of fish gelatin compared to mammalian gelatin. Food Hydrocolloids, Oxford, v.8, p. 203-213, 2004. 
IRWANDI, J.; FARIDAYANTI, S.; MOHAMED, E. S. M.; HAMZAH, M. S.; TORLA, H. H.; CHE MAN, Y. B. Extraction and characterization of gelatin from different marine fish species in Malaysia. International Food Research Journal, v. 16, p. 381 - 389, 2009.

KASANKALA, L. M., XUE, Y., WEILONG, Y., HONG, S. D.; HE, Q. Optimization of gelatin extraction from grass carp (Catenopharyngodon idella) fish skin by response surface methodology, Bioresource Technology, Essex, v. 98, n. 17, 2007.

LENTZ, K. A. Current methods for predicting human food effect - Mini-Review. The AAPS Journal, v. 10, n. 2, p. 282-288, 2008.

LIMA, E. R.; OLIVEIRA, R. A.; AMBROSIO-UGRI, M. C. B.; BARROS, S. T. D.; JÚNIOR, C. B. Recuperação da solução de soda cáustica usada no tratamento do couro bovino na produção de gelatina. Ciência e Tecnologia de Alimentos, Campinas, v. 28, n. 1, p. 98-106, 2008.

MADRONA, G. S.; ZOTARELLI, M. F.; BERGAMASCO, R.; BRANCO, I. G. Estudo do efeito da adição de soro de queijo na qualidade sensorial do doce de leite pastoso. Ciência e Tecnologia de Alimentos, Campina Grande, v. 29, n. 4, p. 862-833, 2009.

MATOS, A. T.; MAGALHAES, M. A.; SARMENTO, A. P. Perda de carga em filtros orgânicos utilizados no tratamento de água residuária de suinoculturas. Engenharia Agrícola, Jaboticabal, v. 30, n. 3, p. 527-537, 2010.

MINAFRA; C. S.; MARQUES; S. F. F.; STRINGHINI, J. H.; ULHOA, C, J.; REZENDE, C. S. M.; SANTOS, J. S.; MORAES, G. H. K. Perfil bioquímico do soro de frangos de corte alimentados com dieta suplementada com alfa-amilase de Cryptococcus flavus e Aspergillus niger HM2003. Revista Brasileira de Zootecnia, Viçosa-MG, v. 39, n. 12, p. 2991-2996, 2010.

MFRURAL. Classificados: Produtos rurais: preço dos pés de frango. Atualizado em 28/01/2010. Disponível em: <http://comprarvender.mfrural.com.br/ detalhe.aspxcdp=44686\&nmoca=procurocompro-compro-pes-de-frango> Acesso em: 22 fev. 2010.

NASCIMENTO, G. A. J.; RODRIGUES, P. B.; FREITAS, R. T. F.; BERTECHINI, A. G.; LIMA, R. R.; PUCCI, L. E. A. Equações de predição para estimar os valores energéticos de alimentos concentrados de origem vegetal para aves utilizando a metanálise. Revista Brasileira de Zootecnia, Viçosa-MG, v. 38, n. 7, p. 1265-1271, 2009.

NASCIMENTO, G. R. do; PEREIRA, D. F.; NÄÄS, I. A.; RODRIGUES, L. H. A. Índice fuzzy de conforto térmico para frangos de corte. Engenharia Agrícola, Jaboticabal, v. 31, n. 2, p. 219-229, 2011.

ORRICO JUNIOR, M. A. P.; ORRICO, A. C. A.; LUCAS JUNIOR, J. Avaliação de parâmetros da biodigestão anaeróbia de dejetos de suínos alimentados com dietas à base de milho e sorgo.

Engenharia Agrícola, Jaboticabal, v. 30, n. 4, p. 600-607, 2010a.

ORRICO JUNIOR, M. A. P.; ORRICO, A. C. A.; LUCAS JUNIOR, J. Compostagem dos resíduos da produção avícola: cama de frangos e carcaças de aves. Engenharia Agrícola, Jaboticabal, v. 30, n. 3, p. 538-545, 2010 b.

ORRICO JUNIOR, M. A. P.; ORRICO, A. C. A. e LUCAS JUNIOR, J. Biodigestão anaeróbia dos resíduos da produção avícola: cama de frangos e carcaças. Engenharia Agrícola, Jaboticabal, v. 30, n. 3, p. 546-554, 2010c.

OSAWA, C. C.; FONTES, L. C. B.; MIRANDA, E. H. W.; CHANG, Y. K.; STEEL, C. J. Avaliação físico-química de bolo de chocolate com coberturas comestíveis à base de gelatina, ácido esteárico, amido modificado ou cera de carnaúba. Ciência e Tecnologia de Alimentos, Campinas, v. 29, n. 1, p. 92-99, 2009. 
OWADA, A. N.; NAAS, I. A.; MOURA, D. J.; BARACHO, M. S. Estimativa de bem-estar de frango de corte em função da concentração de amônia e grau de luminosidade no galpão de produção. Engenharia Agrícola, Jaboticabal, v. 27, n. 3, p. 611 - 618, 2007.

PADILHA, A. C. M; SILVA, T. N. da; SAMPAIO, A. Desafios de adequação à questão ambiental no abate de frangos: o caso da Perdigão Agroindustrial - Unidade Industrial de Serafina Corrêa RS. Teoria e Evidência Econômica, v. 14, p. 109- 125, 2006. Número especial.

ROQUE, V. F.; SELL, I. Alternativas de utilização de resíduos gerados em frigoríficos de aves. 2004. Disponível em: <http://pessoal.utfpr.edu.br/marlenesoares/arquivos /Artigo73.pdf> Acesso em: 27 set. 2009.

ROMAN, J. A.; MENDONÇA, S. N. T. G. de.; SGARBIERI, V. C. Avaliação físico-química, microbiológica, sensorial e atitude do consumidor de gelatina de elevado valor nutricional. Alimentos e Nutrição, Marília, v. 20, n. 1, p. 41-51, 2009.

SALGADO, D. D.; NAAS, I. A. Avaliação de risco à produção de frango de corte do Estado de São Paulo em função da temperatura ambiente. Engenharia Agrícola, Jaboticabal, v. 30, n. 3, p. 367376, 2010.

SANTANA, J. C. C.; DIAS, C. G.; SOUZA, R. R.; TAMBOURGI, E. B. Applying of neural network on the wine sensorial analysis from barbados cherry. Journal of Food Process Engineering, Westport, v. 33, p. 365 - 378, 2010.

SANTOS, T. M. B.; LUCAS JÚNIOR, J.; SILVA, F. M. Avaliação do desempenho de um aquecedor para aves adaptado para utilizar biogás como combustível. Engenharia Agrícola, Jaboticabal, v. 27, n. 3, p. 658-664, 2007.

SCHUMANN, S. P. A.; POLÔNIO, M. L. T.; GONÇALVES, E. C. B. de A. Avaliação do consumo de corantes artificiais por lactantes, pré-escolares e escolares. Ciência e Tecnologia de Alimentos, Campinas, v. 28, n. 3, p. 534-539, 2008.

SEGTNAN, V. H.; ISAKSSON, T. Temperature, sample and time dependent structural characteristics of gelatin gels studied by near infrared spectroscopy. Food Hydrocolloids, Oxford, v. 18, n. 1, p. 1-11, 2004.

SEVERO JUNIOR, J. B.; ALMEIDA, S. S.; NARAIM, N.; SOUZA, R. R.; SANTANA, J. C. C.; TAMBOURGI, E. B. Wine Clarification from Spondias lutea L. Pulp by Hollow Fiber Membrane System, Process Biochemistry, London, v. 42, n. 11, p. 1516-1520, 2007.

SILVA; E. M. da; ROSTON; D. M. Tratamento de efluentes de sala de ordenha de bovinocultura: lagoas de estabilização seguidas de leito cultivado. Engenharia Agrícola, Jaboticabal, v. 30, n. 1, p. $67-73,2010$

SILVA, E.; YANAGI JÚNIOR, T.; BRAGA JÚNIOR, R. A.; LOPES, M. A.; DAMASCENO, F. A.; SILVA, G. C. A. Desenvolvimento e validação de um modelo matemático para o cálculo da área superficial de frangos de corte. Engenharia Agrícola, Jaboticabal, v. 29, n. 1, p. 1-7, 2009.

SILVA, F. A. S.; DUARTE, M. E. M.; CAVALCANTI-MATA, M. E. R. M. Nova metodologia para interpretação de dados de análise sensorial de alimentos. Engenharia Agrícola, Jaboticabal, v. 30, n. 5, p. 967-973, 2010.

UBA. União Brasileira de Avicultura. Relatório anual 2009. Brasília 2009. Disponível em: <http://www.uba.org.br> acesso em: 12 jul. 2010.

XAVIER, C. A. N.; LUCAS JUNIOR, J. Parâmetros de dimensionamento para biodigestores batelada operados com dejetos de vacas leiteiras com e sem uso de inóculo. Engenharia Agrícola, Jaboticabal, v. 30, n. 2, p. 212-223, 2010. 